\title{
27
}

\section{A view from the Electoral Commission}

\section{Graham Leung}

Whatever one's views about the success or otherwise of Fiji's 2006 general election, there seems to be a consensus that there is a need for a wide-ranging, thorough and critical examination of Fiji's voting laws, not least of the country's 'alternative vote system'.

Clearly, the Electoral Commission has a role to play in spearheading discussions aimed at developing bipartisan support for electoral reform. Some of the issues that emerged from the 2006 election are by no means new; they have been raised in the past by various observers. However, between general elections, very little appears to have been done to promote debate on the country's electoral laws and system. It is evident that, unless there is a concerted effort to address these issues, they will arise time and again.

While section 56 of Fijis 1997 constitution makes casting a vote in general elections compulsory, there has never been any attempt to ascertain whether or not every registered voter does indeed cast a ballot. The anecdotal evidence suggests that many people did not cast a ballot in any of the 1999, 2001 and 2006 general elections. Despite this, there is little evidence of people who did not do so being prosecuted. While there are competing arguments for the retention of section 56 of the constitution, there is much to be said for discarding a law that is not being enforced and that is difficult to enforce; laws that cannot be enforced bring the legal system into disrepute and may even encourage noncompliance. On the other hand, a compelling argument can also be mounted 
that not casting a ballot is as much an expression of the democratic choice of a voter, as is casting one. Whatever the arguments, it seems to me that the law on 'compulsory voting' in Fiji needs revisiting to determine whether or not it has succeeded in meeting the objective of its architects.

Under the electoral regulations of the 1970s and 1980s, and again under the Electoral Decree of 1992, the Returning Officer had the discretion to allow a vote which might otherwise have been discarded as invalid, where the voter's intention was clear. In the Electoral Act 1998, this provision was removed. While the number of invalid votes fell in the 2006 general election - down to 8.7 per cent compared with 11.8 per cent in the 2001 election - many commentators have observed that this figure is still too high and must be reduced even further. Although precise figures are not available, information gleaned from election officials at the count centre suggests that the format of the ballot paper may create confusion in the minds of the voters. In many instances votes were declared 'invalid' because the voter had ticked above and below the line. Arguably in some cases, the voters' intention was obvious. But the current law is quite clear, a voter cannot tick both above and below the line. Given this situation, there appears to be a strong argument for the restoration of the discretionary power of the Returning Officer.

Fears that giving the Returning Officer the power to validate votes is giving the officer too much power, could be misplaced as there are checks and balances. First, there must be a 'finding' that the voter's intention is clear. Furthermore, the presence of party agents at the count increases the level of transparency and ensures that only valid votes are counted. The restoration of the discretionary power would ensure that the highest number of valid votes are counted, and reduce the number of voters that are inadvertently disenfranchised.

Sections 130 and 131 of the Electoral Act deal respectively with bribery and undue influence of voters. Section 131 makes it an offence for any person to hinder or interfere with the free exercise or performance by any other person of any political right or duty. Since voting was first introduced in Fiji, party sheds, banners and the serving of kava have been accepted and indeed encouraged by political parties as part of the overall election process - even though many political parties often complain about the expense associated with erecting and staffing the sheds. It is difficult to ignore the reality that, despite voters visiting 
the sheds to obtain assistance, the process often influences the way in which they vote. This influence can take various forms - ranging from voters being given how-to-vote cards to more subtle means of coercion and influence. Electoral laws neither expressly permit nor prohibit the sheds. There is only the caveat that they be no closer than 50 metres from the polling station. Given the need to improve the ethical environment under which polling is conducted so that elections are 'freer and fairer', parliament should, in consultation with relevant stakeholders, give serious consideration to the banning of party sheds. Voters should proceed directly to election officials to obtain their registration details and ballot papers. While no reliable evidence is available, the possibility of some voters being inadvertently misled or improperly advised on how to cast accurate votes cannot be ruled out. Banning party sheds, while perhaps making the atmosphere of elections less 'carnival-like', is likely to increase the ability of voters to cast their votes independently.

Section 164 of the Electoral Act empowers the Electoral Commission to make regulations prescribing 'all matters required or permitted' by the Electoral Act or 'necessary or convenient to be prescribed for carrying out or giving effect' to the Act to be prescribed. Presently, there are regulations on only a limited range of issues. In the past, the Electoral Commission has used its regulationmaking powers sparingly, if at all. I would suggest that it is timely for the Electoral Commission to consider taking a more robust attitude with regard to the exercise of its statutory powers in this regard. Under section 164(2) of the Electoral Act, there is clearly enormous potential for the Electoral Commission to introduce wide-ranging measures aimed at improving the transparency and conduct of general elections. These regulations would have the force of law and bring about greater uniformity and accountability in election administration, thus assisting the Supervisor of Elections and his/her staff.

Many useful, if not altogether new, recommendations have emerged from the various missions that were present in Fiji to observe the 2006 general election. The Electoral Commission hopes to complete a comprehensive review of the general election before the end of 2006. The expectation is that it should then be in a good position to develop a strategy for the conduct of future elections in Fiji. This strategy is likely to have, as a high priority, the establishment of a State Elections Office. 